\title{
Revien \\ Agricultural entomology in the state of Acre, Brazil: a historical overview and future challenges
}

\author{
Weidson Plauter Sutil1 $\&$ Rodrigo Souza Santos ${ }^{2} \bowtie$
}

\author{
1. Universidade Federal do Acre (UFAC) - Programa de pós-graduação em Produção Vegetal. 2. Laboratório de Entomologia - Embrapa \\ Acre. $^{2}$
}

\section{EntomoBrasilis 13: e0878 (2020)}

\author{
Edited by: \\ William Costa Rodrigues \\ Article History: \\ Received: 21.x.2019 \\ Accepted: 06.ii.2019 \\ Published: 20. ii.2020 \\ Corresponding author: \\ Rodrigo Souza Santos \\ B rodrigo.s.santos@embrapa.br \\ (1) orcid.org/0000-0002-0879-0049
}

\section{Funding agencies: \\ $\Delta$ Without funding declared}

\begin{abstract}
Family-based agriculture is predominant in the state of Acre, Brazil. Although it has less economic impact in relation to large-scale plantations, it is also subject to biological imbalances, such as pest attacks, generating economic losses for producers. Phytosanitary knowledge is still incipient in this Brazilian state and it becomes an obstacle to production, often resulting in mistaken management decisions. In this context, this work aimed to present a history of two decades of research in the area of Agricultural Entomology, especially in the areas of integrated management and biological pest control of the most relevant crops grown in Acre state. In this review, 58 scientific papers related to Agricultural Entomology were presented, 23 on surveys and/or new insect records and/or new insect associations with host plants, 17 on insect control using plant extracts from the Amazon region, 13 on integrated pest management and five on bioecology, action levels and/or population dynamics of insect pests in the state of Acre. Through this review, it is observed that basic researches in the area of Agricultural Entomology (surveys, new species record, bioecological or dynamic population studies) have been carried out in this area of the Amazon. Despite a remarkable advance in scientific studies related to integrated pest management in the state in the past ten years, still there is a need to concentrate efforts on research aimed at prospecting and using Amazonian biodiversity (fauna and flora), which subsidize applied programs for integrated pest management of the main crops grown in the state of Acre.
\end{abstract}

Keywords: Agricultural pests; Biological Control; Integrated pest management; Phytosanity; Western Amazon. cause considerable financial losses. It is estimated that the attacks caused by these insects result in economic losses of billions of Brazilian reais annually for the economy (RANGEL 2015).

The lack of technologies that improve productivity and technical information are some of the problems faced by family farmers in the state of Acre (ANDRADE Neto et al. 2011b; Nogueira et al. 2013). Research institutions such as the Brazilian Agricultural and Research Corporation (Embrapa) and universities, through postgraduate programs, are the main sources of knowledge generation and responsible for the transfer of technology to producers in the state.

In this context, this work aimed to present the 'state of the art' regarding Agricultural Entomology researches carried out in the state of Acre in the last two decades. To this end, the publications listed in the Lattes Curriculum of all the entomologists (professionals and students) who work or have worked in this area of research in the state were consulted. The databases consulted were: Capes journals portal, Scielo platform and Ainfo journals portal - Embrapa's documents and digital collection management system. Book chapters, articles and scientific notes published in indexed journals, research bulletins, circulars and technical communications, documents from the Embrapa's series, as well as expanded abstracts were consulted. The research focused particularly on studies related to integrated management and biological pest control of the main agricultural crops in this state. negative interference of insect pests in plantations may 


\section{Pasture pests (Brachiaria spp.)}

Considered the main pasture pests, they attack pastures in high humidity season causing severe damages that vary for each grass species. In the state of Acre there is evidence of the occurrence of the species Deois flavopicta Stall, Deois incompleta Walker, Notozulia entreriana Berg and Mahanarva tristis Fabricius (Hemiptera: Cercopidae). Particular attention should be paid to the attack by M. tristis, a species that causes the highest level of injury to pastures in the state (FAzouIn et al. 2009a; FAzolin et al. 2016a).

Avant-garde studies were carried out in the past century, evaluating the resistance of grasses to the attack of leafhoppers (FAzolin \& KouRI 1984) and the use of fire as a controlling agent for these insects (FAzolin \& KourI 1985). FAzoLIn et al. (2009a) carried out work on population dynamics of leafhoppers in pastures of Brachiaria humidicola (Rendle) (Poaceae) and survey of insects associated with TannerGrass, Tangola and African Star Grass, respectively. These authors evaluated the consortium of different cultivars of Brachiaria as a mechanism to control leafhoppers.

In addition to typical grasshoppers, other pests of lesser relevance are reported for grasses in Acre state. FAzoLIN et al. (2009a), recorded the attack of grass bug, Blissus antillus Leonard (Hemiptera: Lygaeidae) and Spodoptera frugiperda J. E. Smith (Lepidoptera: Noctuidae). However, these attacks are reported as sporadic and there are no other studies and reports.

\section{Peanut pests (Arachis spp.)}

In the state of Acre there are two important pest species associated with forage peanuts, Arachis pintoi Krapov \& Gregory (Fabaceae), the carmine spider mite: Tetranychus ogmophallos Ferreira \& Flechtmann (Acari: Tetranychidae) and the lace bug: Gargaphia paula Drake \& Ruhoff (Hemiptera: Tingidae) (Guidoti et al. 2004; Fazolin et al. 2015a)

SANTos (2016) e SiLva et al. (2018) conducted works observing the population dynamics of $T$. ogmophallos and G. Paula in two forage peanut plots without application of phytosanitary products. It was observed that the population peaks of T. ogmophallos, in pure and hybrid accessions of $A$. pintoi, occurred in the months of August to November under the edaphoclimatic conditions of the state of Acre. SAntos \& MouRA (2017a) carried out a survey of insects associated with edible peanuts, Arachis hypogaea L. (Fabaceae), reporting the occurrence of 26 different insect species associated with peanuts, belonging to three orders, with wide dominance of coleopterans. Among these, Disonycha brasiliensis Costa Lima and Cerotoma arcuata tingomariana Bechyné (Coleoptera: Chrysomelidae) were reported as the first records of association with peanuts plants in Brazil, as well as potential pests to culture in the state.

\section{Coffee pests (Coffea canephora Pierre ex Froehner)}

FAzolin et al. (2012a) reported the presence of coffee borer Hypothenemus hampei Ferrari (Coleoptera: Curculionidae) and the leaf miner, Leucoptera coffeella Guérin-Menéville (Lepidoptera: Lyonetiidae) in Acre state.

Studies on coffee pests in the state are scarce, with only two published works, a record of coffee borer infestation and management guidelines for Coffea canephora Pierre ex Froehner (Rubiaceae), commonly known as Conilon coffee, made by Fazolin et al. (2000a).

Martins et al. (2019) assessed the diversity and abundance of chrysopids (Neuroptera: Chrysopidae) in irrigated and nonirrigated experimental planting of Conilon coffee, indicating
Ceraeochrysa cubana Hagen (Neuroptera: Chrysopidae) as a promising species to be used in biological pest control programs in the state of Acre.

\section{Fruit pests in general}

Thomazinı et al. (2003) made the first records of fruit flies of the genus Anastrepha (Diptera: Tephritidae) for the Acre state, in samples in the municipality of Rio Branco.

Until 2010 the species of fruit flies reported in the state of Acre were: Anastrepha coronilli Carrejo \& González, Anastrepha distincta Greene, Anastrepha leptozona Hendel, Anastrepha obliqua Macquart, Anastrepha striata Schiner and Anastrepha tumida Stone (Thomazini et al. 2003; Pereira et al. 2010). Later, Adaime et al. (2017) and Azevedo et al. (2018) reported the first records of species Ceratitis capitata (Wiedemann) and Anastrepha serpentina (Wiedemann) (Diptera: Tephritidae) for the state, respectively.

Currently, eight species of Tephritidae (seven species of Anastrepha, besides C. capitata) and two of Lonchaeidae are reported for the state (ADAIME et al. 2016; AzEVEDo et al. 2018). In addition to these species, Vasconcelos et al. (2017) also mentioned the first record of Zaprionus indianus Gupta (Diptera: Drosophilidae), known as fig-fly, a frugivorous species of less economic importance in the state. With regard to the natural enemies of these pests, THOMAZINI \& Albuquerque (2009), made the first records of parasitoids of Anastrepha in the Acre state, being Opius bellus Gahan, Doryctobracon areolatus Szépligeti and Utetes anastrephae Viereck (Hymenoptera: Braconidae) associated with $A$. obliqua in taperebá fruits, in the municipality of Bujari and $D$. areolatus associated with $A$ obliqua in guava fruits, in the municipality of Rio Branco. Posteriorly, Azevedo et al. (2018) described the first occurrence of the parasitoid Asobara anastrephae (Muesebeck) in fruits of Spondias mombin L. (Anacardiaceae), infested by $A$. obliqua collected in the municipality of Rio Branco.

\section{Açai palm pests (Euterpe oleracea Mart.)}

The first record of the occurrence of leafhopper, Aetalion reticulatum (L.) (Hemiptera: Aethalionidae), associated with açai tree clump plants, Euterpe oleracea Mart. (Arecaceae) in Acre state, was carried out by SANTOS et al. (2015). Then, AndRADE Neto et al. (2016) reported the first infestation of the caterpillar Herminodes sp. (Lepidoptera: Noctuidae) attacking a commercial plantation of $E$. oleracea in the municipality of Bujari.

SANTOS \& COSTA (2019), increased knowledge about the natural enemies of leafhoppers in the State, reporting the first occurrence of Pterygogramma marquesi Brèthes (Hymenoptera: Trichogrammatidae) in A. reticulatum eggs. The authors report that this egg parasitoid has the potential to be used in an applied biological control program to this pest in the state, requiring studies related to rearing the species in the laboratory.

\section{Banana pests (Musa spp.)}

The banana root weevil Cosmopolites sordidus Germar (Coleoptera: Curculionidae) is considered one of the main banana pests in the state of Acre, with wide distribution in the state. Fazolin et al. (1990, 2000b) carried out pioneering work on the integrated management of this pest, evaluating the effect of three insecticides on its control and the attractiveness of homemade traps made with the pseudostem. Fazolin \& SANTOS (2017), describe technical instructions with step by step containing the main methods for the control of the banana root weevil. 
FAzouIn et al. (2012a), reported the giant borer Telchin licus Drury (Lepidoptera: Castniidae) occurring in banana plants in Acre state. Subsequently, Fazolin \& SANTOS (2017), point out the giant borer as the main pest of cultivar D'Angola (long banana) in the state of Acre, causing severe damage to infested crops. Research related to the control of the giant borer is strongly necessary, given the damage that this species causes in the cultivation and the economic importance of this culture for the state of Acre.

Kochemborger et al. (2016), made the first report of the occurrence of Metamasius hemipterus (L.) (Coleoptera: Curculionidae) in banana crops in Acre state, a species that is not known to cause economic damage to the banana crop, but when at a high population level it can cause damage the culture.

\section{Cassava pests (Manihot spp.)}

Fazolin \& Estrela (2016) described the main cassava pests for the Amazon region, recording only the occurrence of mandarová, Erinnyis ello (L.) (Lepidoptera: Sphingidae) for the Acre state. Due to the successive outbreaks in the state, the mandarová gained special attention making it necessary that measures were adopted for its control.

FAzolın et al. (2007a) describes various methods of controlling mandarová within integrated pest management, together with examples of experiences of controlling this pest in the Juruá's Valley. Fazolin et al. (2007b) present seven steps to control this species, in addition to conducting evaluations of the efficiency of the use of Baculovirus erinnyis (Baculoviridae), reaching mortality of $96 \%$ of the caterpillars, demonstrating a high effectiveness in combating this pest. SIHLER et al. (2016) presented the characterization of a Baculovirus isolate that occurs in natural populations of $E$. ello in the municipality of Cruzeiro do Sul, a viable, safe and economical alternative for the control of mandarová.

With regard to natural enemies, SANTOS et al. (2017c) verified the first occurrence of the endoparasitoid Brachymeria annulata Fabricius (Hymenoptera: Chalcididae) in pre-pupae of $E$. ello, in the municipality of Epitaciolândia, in infestation of this species in rubber trees cultivation.

SANTOS et al. (2019a) increased knowledge about the geographic distribution of two species of lace bugs associated with cassava cultivation in the state of Acre, reporting the first record of occurrence of Vatiga manihotae Drake, Vatiga illudens Drake and Gargaphia opima Drake (Hemiptera: Tingidae) in the Kaxinawá indigenous land of Nova Olinda, municipality of Feijó, the latter being, the first record for Brazil.

\section{Corn pests (Zea mays L.)}

The works in the field of Agricultural Entomology, published in the state of Acre on the culture of corn, refer to the management and control of Lepidoptera and Coleoptera associated with the crop. In the state, the presence of the following pests is reported: fall armyworm, S. frugiperda, corn weevil, Sitophilus zeamais Motsch (Coleoptera: Curculionidae) and maize cob borer, Helicoverpa zea Boddie (Lepidoptera: Noctuidae) (FAzolin et al. 2012a).

The works carried out in the state aiming at the management of corn weevil refer to the use of alternative methods to conventional chemical control, with evaluation of the insecticidal potential and toxic effect found in several plants found in the Amazon region (Estrela et al. 2006; Fazolinet al. 2007c; Fazolin et al. 2009b; Fazolin et al. 2010; Fazolin et al. 2012b; SANTOS et al. 2019b).
Regarding the control of the fall armyworm, the studies are divided between studies with the essential oil of monkey's pepper, Piper aduncum L. (Piperaceae) (botanical insecticide), chemical insecticides and studies of synergistic effects between the two. Aiming to provide options for the management of $S$. frugiperda resistance to chemical insecticides, FAzouIn et al. (2015b, 2016b, 2016c, 2017a) evaluated the combination of the essential oil of $P$. aduncum with 15 conventional chemical active ingredients. Almeida et al. (2017) analyzed the efficiency of six active ingredients mixed with copaiba oil-resin. SANTOs et al. (2015, 2016b, 2016c) observed the insecticidal potential of pure oils from 11 plant species in the control of the caterpillar, indicating the efficiency of Copaiba (Copaifera sp., Fabaceae), Babassu (Orbignya phalerata Mart., Arecaceae) and Crapwood (Carapa guianensis Aubl., Meliaceae).

\section{Bean pests [Phaseolus vulgaris L., Vigna unguiculata (L.) and Canavalia ensiformis L.]}

Several basic studies were carried out involving insect pests of common bean in Acre state, these being the effect of population levels of Cerotoma sp. on the yield of Vigna unguiculata (L.) (cowpea bean) (FAzoLIN 1986), evaluation of cowpea seeds for the attack of Callosobruchus analis Fabricius (Coleoptera: Bruchidae) in different types of storage, description of damage and population dynamics of pests and enemies natural of cowpea (FAzOLIN \& MEsQuita 1993), determination of the action level for the control of Cerotoma tingomarianus Bechyné (FAzoLIN. 1986) and determination of the level of economic damage of that rootworm in Phaseolus vulgaris L. (Fazolin et al. 2001; Fazolin \& Estrela 2004).

SANTOS et al. (2017b) reported the first occurrence of the lace bug, Gargaphia lunulata Mayr (Hemiptera: Tingidae), associated with the jack bean, Canavalia ensiformis L. (Fabaceae) in the Acre state, this plant being a new host for this species in Brazil.

The studies related to management are all directed to the control of the bean's rootworm (C. tingomarianus), using plant extracts as control alternatives. Fazolin et al. (1997, 2002) evaluated the insecticidal potential of several exotic or native plants in the Amazon region aiming to control this pest. Fazolin et al. (2005) and Alecio et al. (2010) qualified the toxicity of the essential oil of $P$. aduncum e and the insecticidal action of the extract of Derris amazonica Killip (Fabaceae) in the management of rootworms in beans, respectively.

Complete information was published in the form of book chapters on the pest complexes associated with the cultivation and storage of beans in the Amazon (FAzolin et al. 2016c, 2016e), as well as information for carrying out alternative pest control in their cultivation and storage. (Fazolin et al. 2016f).

\section{Final Considerations}

In this literature review, 66 scientific publications were listed, of which 58 are related to the area of Agricultural Entomology. Of these 58 studies, 23 refer to surveys or new insect records for the state of Acre, 17 on insect control using plants from the Amazon region, 13 adhering to integrated pest management [chemical control (chemical and/or botanical insecticides), biological (parasitoids and/or entomopathogens), resistance of plants to insects or alternative methods of control] and five on bioecology and population dynamics of insect pests in Acre state.

Many other entomological studies are reported for the state of Acre. However, this review covered works in the area of Agricultural Entomology, without including those published 
in the form of simple abstracts. In addition, the scope of this work focused on the areas of biological management and control, of the pests of the crops of greatest economic relevance for the State.

In this review, it was found that most of the literature published in the area of Agricultural Entomology in the state of Acre is available in the form of simple abstracts, which limits its dissemination and practical use of information.

Although most research in the field of Agricultural Entomology is characterized as basic research, through this history, it has been observed that this research area has evolved in recent years, with research focused on integrated management, especially those focused on the use of plants in the Amazon region with potential insecticide. Although this scientific advance is notorious, there is still a need for research aimed at the prospection and use of local biodiversity (fauna and flora), which subsidize integrated management programs and applied biological control, concerning the main pests of Acre agriculture.

The Acre state is located in a region rich in biodiversity, bordering Peru and Bolivia. Thus, the possibility of entry of pests (including new ones) from neighboring countries is feasible. However, there is a great possibility of discovering new species of natural enemies (parasitoids, predators and entomopathogens), as well as plants with insecticidal activity, with great potential to be used in integrated pest management programs in this region of the Western Amazon.

\section{REFERENCES}

Adaime, R, MSM Sousa \& JF Pereira, 2016. Anastrepha species and their host in the Brazilian Amazon. Available on: <http://anastrepha.cpafap.embrapa.br>. [Access in: 17.ii.2020].

Adaime, R, RS Santos, TS Azevedo, AS Vasconcelos, MSM de Souza \& MF Souza-Filho, 2017. First record of Ceratitis capitata (Wiedemann) (Diptera: Tephritidae) in the state of Acre, Brazil. EntomoBrasilis, 10: 259-260. DOI: https://doi.org/10.12741/ebrasilis.v10i3.724

Alecio, MR, M Fazolin, RA Coelho Neto, V Catani, JLV Estrela, SB Alves, RS Correa, RC Andrade Neto \& AD Gonzaga, 2010. Ação inseticida do extrato de Derris amazonica Killip para Cerotoma arcuatus Olivier (Coleoptera: Chrysomelidae). Acta Amazonica, 40: 719-728. DOI: https://doi.org/10.1590/S0044-5967201000040001

Almeida, WA de, IHL da Silva, ACV dos Santos, AP Barros Junior \& AH de Sousa, 2017. Potentiation of copaiba oil-resin with synthetic insecticides to control of fall armyworm. Revista Caatinga, 30: 1059-1066. DOI: https://doi.org/10.1590/1983-21252017v30n427r

Amaral, EF, JF Valentim, JL Lani, NG Bardales \& EA Araújo, 2006. Áreas de risco de morte de pastagens de Brachiaria brizantha cultivar Marandu, com o uso da base de dados pedológicos do zoneamento ecológico-econômico no Estado do Acre. pp. 151-174. In: Barbosa, RA (Org.). Morte de pastos de braquiárias. $1^{a}$ ed. Campo Grande, MS: Embrapa Gado de Corte. 206 p.

Andrade Neto, R de C, JRS Negreiros, Araújo Neto SE de, MJB Cavalcante, MR Alécio \& RS Santos, 2011a. Diagnóstico da potencialidade da fruticultura no Acre. Rio Branco, AC: Embrapa Acre (Documentos, 125), 36 p.

Andrade Neto, R de C, JRS Negreiros, Araújo Neto SE de, MJB Cavalcante, MR Alécio \& RS Santos, 2011b. Gargalos tecnológicos da fruticultura no Acre. Rio Branco, AC: Embrapa Acre (Documentos, 123), 55 p.

Andrade Neto, R de C, JR de Oliveira, AMP Lunz, SR Nogueira, RS Santos, UO de Almeida, DA da Costa \& JM de Araújo, 2016. Ocorrência e danos causados pela lagarta Herminodes sp. (Lepidoptera: Noctuidae) em cultivos de açaizeiro
(Euterpe oleracea Mart.) no Estado do Acre. Rio Branco, AC: Embrapa Acre (Documentos, 148), 22 p.

Azevedo, TS, AS Vasconcelos, RS Santos, MSM de Sousa \& R Adaime, 2018. Levantamento de moscas frugívoras em dois municípios do estado do Acre, Brasil. Biotemas, 31: 25-31. DOI: https://doi.org/10.5007/2175-7925.2018v31n3p25

CONAB (Companhia Nacional de Abastecimento), 2018. Perspectivas para a agropecuária. Available on: <https:// www.conab.gov.br/perspectivas-para-a-agropecuaria>. [Access in: 17.ii.2020].

Estrela, JLV, M Fazolin, V Catani, MR Alécio \& MS de Lima, 2006. Toxicidade de óleos essenciais de Piper aduncum e Piper hispidinervum em Sitophilus zeamais. Pesquisa Agropecuária Brasileira, 41: 217-222. DOI: https://doi.org/10.1590/S0100-204X2006000200005

Fazolin, M \& J Kouri, 1984. Introdução de gramíneas visando resistência à cigarrinhas-das-pastagens no estado do Acre. Rio Branco, AC: Embrapa Acre (Pesquisa em andamento, 37), $2 \mathrm{p}$.

Fazolin, M \& J Kouri, 1985. Utilização do fogo como agente de controle das cigarrinhas-das-pastagens em Brachiaria decumbens no Estado do Acre. Rio Branco, AC: Embrapa Acre (Pesquisa em Andamento, 38), 6 p.

Fazolin, M, 1986. Efeito de diferentes níveis populacionais de Cerotoma sp. no rendimento do caupi (Vigna unguiculata (L.) Walp). Rio Branco, AC: Embrapa Acre (Comunicado Técnico, 49), $7 \mathrm{p}$.

Fazolin, M, LV Pereira \& CF Wilcken, 1990. Influência de três inseticidas sobre o controle e atratividade de Cosmopolites sordidus (Germar, 1824) (Coleoptera: Curculionidae) em iscas tipo queijo, no Município de Rio Branco (AC). Anais da Sociedade Entomológica do Brasil, 19: 181-189.

Fazolin, M \& JE de L Mesquita, 1993. Avaliação de sementes de caupi quanto ao ataque do caruncho em diferentes condições de armazenamento. Rio Branco, AC: Embrapa Acre (Comunicado Técnico, 46), $9 \mathrm{p}$.

Fazolin, M, JLV Estrela \& VM Argolo, 1997. Seleção de substâncias no controle da vaquinha do feijoeiro Cerotoma tingomarianus Bechyné (Coleoptera: Chrysomelidae). Rio Branco, AC: Embrapa Acre (Pesquisa em Andamento, 108), 5 p.

Fazolin, M, R de CA Pereira \& F de Sales, 2000a. Infestação e medidas preventivas no manejo da broca do cafeeiro Hypothenemus hampei (Ferrari, 1867) nas linhagens de café Robusta e Conilon em Rio Branco, AC. Rio Branco, AC: Embrapa Acre (Circular Técnica, 111), 2 p.

Fazolin, M, AS Ledo \& FF de Azevedo, 2000b. Manejo preventivo da broca-do-rizoma da bananeira no Acre. Rio Branco, AC: Embrapa Acre (Comunicado Técnico, 110), 3 p.

Fazolin, M, J de Sá Pessoa, DL do Amaral Júnior, WSA de Oliveira \& CR da Costa, 2001. Determinação do nível de ação para o controle da vaquinha-do-feijoeiro no Acre. Rio Branco, AC: Embrapa Acre (Comunicado Técnico, 134), 4 p.

Fazolin, M, JLV Estrela, AP de Lima \& VM Argolo, 2002. Avaliação de plantas com potencial inseticida no controle da Vaquinha-do-feijoeiro (Cerotoma tingomarianus Bechyné). Rio Branco, AC: Embrapa Acre (Boletim de Pesquisa e Desenvolvimento, 37), $42 \mathrm{p}$.

Fazolin, M \& JLV Estrela, 2004. Determinação do nível de dano econômico de Cerotoma tingomarianus Bechyné (Coleoptera: Chrysomelidae) em Phaseolus vulgaris L. cv. Pérola. Neotropical Entomology, 33: 631-637. DOI: https:// doi.org/10.1590/S1519-566X2004000500014

Fazolin, M, JLV Estrela, V Catani, MS de Lima \& MR Alecio, 2005. Toxicidade do óleo de Piper aduncum L. a adultos de Cerotoma tingomarianus Bechyné (Coleoptera: Chrysomelidae). Neotropical Entomology, 34: 485-489. DOI: https://doi.org/10.1590/S1519-566X2005000300018

Fazolin, M, JLV Estrela, MD Campos Filho, ACC Santiago \& FS Frota, 2007a. Manejo integrado do mandarová-damandioca Erinnyis ello (L.) (Lepidoptera: Sphingidae): 
conceitos e experiências na região do Vale do Rio Juruá, Acre. Rio Branco, AC: Embrapa Acre (Documentos, 107), $45 \mathrm{p}$.

Fazolin, M, JLV Estrela, MD Campos Filho, ACC Santiago \& FS Frota, 2007b. Sete passos para controlar o mandarová-damandioca. Rio Branco, AC: Embrapa Acre (Documentos, 108), $18 \mathrm{p}$.

Fazolin, M, JLV Estrela, V Catani, MR Alécio \& MS de Lima, 2007c. Atividade inseticida do óleo essencial de Tanaecium nocturnum (Barb. Rodr.) Bur. \& K. Shum (Bignoneaceae) sobre Sitophilus zeamais Motsch. (Coleoptera: Curculionidae). Acta Amazonica, 37: 599-604. DOI: https://doi.org/10.1590/S0044-59672007000400015

Fazolin, M, CR da Costa, JLV Estrela, CE Hessel \& CMS de Andrade, 2009a. Levantamento de insetos-praga associados aos capins Tanner-grass, Tangola e Estrelaafricana no Acre. Amazônia: Ciência \& Desenvolvimento, 4: 161-173.

Fazolin, M, CR da Costa, ASS Cavalcante, JLV Estrela, ES de Albuquerque, 2009b. Cipó-vick: adaptação do uso tradicional comparado à fosfina no controle do gorgulhodo-milho em paióis. Rio Branco, AC: Embrapa Acre (Documentos, 115), 44 p.

Fazolin, M, CR da Costa, JEO Damaceno, ES de Albuquerque, AS de Cavalcante \&JLV Estrela, 2010. Fumigação de milho para o controle do gorgulho utilizando caule de Tanaecium nocturnum (Bignoniaceae). Pesquisa Agropecuária Brasileira, 45: 1-6. DOI: https://doi.org/10.1590/S0100204X2010000100001

Fazolin, M, MJ, Thomazini \& JLV Estrela, 2012a. Pragas das culturas de importância econômica para o Estado de Acre. Rio Branco, AC: Embrapa Acre (Documento, 127), 68 p.

Fazolin, M, JLV Estrela \& CR da Costa, 2012b. Determination of the concentration of stems of Kangàrà Kanê against of the Sitophilus zeamais Mots., 1855. Magistra, 24: 239-246.

Fazolin, M, GJN de Vasconcelos, EFB Lima, RS Santos \& HN de Azevedo, 2015a. Reconhecimento de artrópodes de importância econômica para o amendoim forrageiro. Rio Branco, AC: Embrapa Acre. (Documento, 137), 64 p.

Fazolin, M, JLV Estrela, AFM Monteiro, LP Gomes, LM da Silva \& MSF Silva, 2015b. Sinérgico alternativo para o manejo da resistência da lagarta-do-cartucho do milho a piretróides. Revista Brasileira de Milho e Sorgo, 14: 316-325. DOI: https://doi.org/10.18512/1980-6477/rbms.v14n3p316-325

Fazolin, M \& JLV Estrela, 2016. Mandioca, pp. 345-363. In: Silva, NM da, R Adaime \& RA Zucchi (Eds.). Pragas agrícolas e florestais na Amazônia. Brasília, DF: Embrapa, 608 p.

Fazolin, M, RS Santos, CMS de Andrade, GML de Assis \& JF Valentim, 2016a. Cigarrinhas-das-pastagens: como identificar e controlar a principal praga das pastagens. Rio Branco, AC: Embrapa Acre/Fundepec. (Folder, 1), 4 p.

Fazolin, M, JLV Estrela, AFM Medeiros, LP Gomes, IM da Silva \& MSF Silva, 2016b. Potencial sinérgico do óleo de Piper aduncum para inseticidas formulados com misturas de princípios ativos. Revista de Ciências Agrárias, 59: 362369. DOI: https://doi.org/10.4322/rca.2389

Fazolin, M, JLV Estrela, AFM Medeiros, IM da Silva, LP Gomes \& MSF Silva, 2016c. Combining the essential oil of Piper aduncum L. with commercial insecticides. Semina: Ciências Agrárias, 37:3903-3914. DOI: https://doi. org/10.5433/1679-0359.2016v37n6p3903

Fazolin, M, JLV Estrela, MR Alecio \& SB Alves, 2016d. Feijão, pp. 345-363. In: Silva, NM da, R Adaime \& RA Zucchi (Eds.). Pragas agrícolas e florestais na Amazônia. Brasília, DF: Embrapa, 608 p.

Fazolin, M, JLV Estrela, MR Alecio \& SB Alves, 2016e. Insetos associados ao cultivo e armazenamento de feijões, pp. 223-248. In: Mattar, EPL, E de Oliveira, RC dos Santos \& A Siviero (Orgs.). Feijões do Vale do Juruá. Rio Branco, AC: IFAC, 2016. 336 p.

Fazolin, M, MR Alecio, JLV Estrela \& SB Alves, 2016f. Controle alternativo de pragas para o cultivo e armazenamento de feijões. pp. 249-297. In: Mattar, EPL, E de Oliveira, RC dos Santos \& A Siviero (Orgs.). Feijões do Vale do Juruá. Rio Branco, AC: IFAC. 336 p.

Fazolin, M \& RS Santos, 2017. Pragas. In: Sistema de produção de banana para o Estado do Acre. Rio Branco: Embrapa Acre (Sistemas de Produção, 7). Available on: <https://ainfo.cnptia.embrapa.br/digital/bitstream/ item/164523/1/26273.pdf>. [Access in: 17.ii.2020].

Fazolin, M, JLV Estrela, AFM Monteiro, LM da Silva \& LP Gomes, 2017a. Sinérgico alternativo para inseticidas inibidores de acetilcolinesterase. Revista Agro@mbiente On-line, 11: 232-240. DOI: https://doi.org/10.18227/1982-8470ragro. v11i3.3995

Guidoti, M, RS Santos, M Fazolin \& HN de Azevedo, 2014. Gargaphia paula (Heteroptera: Tingidae): first host plant record, new geographic data and distribution summary. Florida Entomologist, 97: 322-324. DOI: https://doi.org/10.1653/024.097.0152

Kochemborger, J, LL Martins, ECS Junior \& AH de Sousa, 2016. Ocorrência de Metamasius hemipterus (Coleoptera: Curculionidae) em cultivos de bananeira no município de Senador Guiomard, Acre, Brasil. Revista de Biologia e Ciências da Terra - BIOTERRA, 16: 15-18.

Martins, CC, RS Santos, WP Sutil \& JFA Oliveira, 2019. Diversidade e abundância de crisopídeos (Neuroptera: Chrysopidae) em cultivo de café Conilon no Acre, Brasil. Acta Amazonica, 49: 173-178. DOI: https://doi.org/10.1590/1809-4392201804470

Nogueira, SR, RC Andrade Neto, GC Nascimento, MJB Cavalcante, A Siviero \& RS Santos, 2013. Bananicultura acriana: situação atual e desafios. Rio Branco, AC: Embrapa Acre (Documentos, 131), 36p.

Pereira, JDB, DP Buriti, WP Lemos, WR Silva \& RA Silva, 2010. Espécies de Anastrepha Schiner (Diptera: Tephritidae), seus hospedeiros e parasitoides nos Estados do Acre e Rondônia, Brasil. Biota Neotropica, 10: 441-446. DOI: https://doi.org/10.1590/s1676-06032010000300037

Rangel, LEP, 2015. Perdas e danos para o agronegócio. Agroanalysis, 35: 30-31.

Santos, ACV, CC Fernandes, LM Lopes \& AH Sousa, 2015. Use of plant oils from the southwestern Amazon for the control of maize weevil. Journal of Stored Products Research, 63: 67-70. DOI: https://doi.org/10.1016/j.jspr.2015.07.002

Santos, ACV dos, CC Fernandes, LM Lopes \& AH de Sousa, 2016a. Insecticidal oils from amazon plants in control of fall armyworm. Revista Caatinga, 29: 642-647. DOI: https:// doi.org/10.1590/1983-21252016v29n314rc

Santos, ACV dos, WA de Almeida, CC Fernandes \& AH de Sousa, 2016b. Hydroalcoholic plant extracts from the southwest Amazon for the alternative control of fall armyworms. Idesia (Arica), 34: 63-67. DOI: https://doi.org/10.4067/ s0718-34292016005000019

Santos, MBH \& MBJ Bernardes, 2018. O uso dos agrotóxicos no Brasil: suas implicações e desafio. Espaço em Revista, 20: 29-42.

Santos, RS, 2016. Infestação de Tetranychus ogmophallos Ferreira \& Flechtmann (Acari: Tetranychidae) em amendoim forrageiro (Arachis pintoi Krapov. \& Greg.) nos Estados do Acre e Minas Gerais. EntomoBrasilis, 9: 69-72. DOI: https://doi.org/10.12741/ebrasilis.v9i1.563

Santos, RS, AJ Creão-Duarte \& AMP Lunz, 2015. Infestação de Aetalion reticulatum (Linnaeus) (Hemiptera: Auchenorrhyncha: Aethalionidae) em plantas de Euterpe oleracea Martius (Arecaceae) no Estado do Acre. EntomoBrasilis, 8: 69-73. DOI: https://doi.org/10.12741/ ebrasilis.v8i1.450

Santos, RS \& LA Moura, 2017a. Entomofauna associada ao amendoinzeiro em Rio Branco, Acre, Brasil. Agrotrópica, 29: 167-172. DOI: https://doi.org/10.21757/01033816.2017v29n2p167-172 
Santos, RS, FT Hata, LBN Coelho \& MU Ventura, 2017b. Registros de ocorrência e novos hospedeiros de Gargaphia lunulata (Mayr) (Hemiptera: Tingidae) nos estados do Acre e Paraná. EntomoBrasilis, 10: 254-258. DOI: https://doi.org/10.12741/ebrasilis.v10i3.714

Santos, RS, MT Tavares, WP Sutil, A Vasconcelos, TS Azevedo \& BS Diogo, 2017c. Parasitismo de Brachymeria annulata (Fabricius) (Hymenoptera: Chalcididae) em Erinnyis ello (L.) (Lepidoptera: Sphingidae). In:V Congresso Online de Agronomia (Convibra). 7 p.

Santos, RS \& VA Costa, 2019. Pterygogramma marquesi (Hymenoptera: Trichogrammatidae): inimigo natural da cigarrinha-das-frutíferas no Acre. Rio Branco, AC: Embrapa Acre (Eventos Técnicos \& Científicos, 1), $5 \mathrm{p}$.

Santos, RS, LBN Coelho \& APGS Wengrat, 2019a. Percevejosde-renda (Hemiptera: Tingidae) associados ao cultivo da mandioca na terra indígena Kaxinawá de Nova Olinda, Acre, com novo registro para o Brasil. EntomoBrasilis, 12: 93-96. DOI: https://doi.org/10.12741/ebrasilis.v12i2.836

Santos, RS, A Siviero, SR Nogueira, PEF Macedo \& M Haverroth, 2019b. Pragas e doenças da terra indígena Kaxinawá de Nova Olinda e práticas agroecológicas de controle. pp. 293-335. In: Siviero, A, RC dos Santos \& EPL Mattar (Orgs.). Conservação e tecnologias para o desenvolvimento agrícola e florestal no Acre. Rio Branco, AC: IFAC. 788 p.

Sihler, W, MM Sanches, R Falcão, M Fazolin, JLV Estrela \& ML de Sousa, 2016. Caracterização de baculovírus patogênico ao mandarová-da-mandioca (ErelGV) procedente de Cruzeiro do Sul, Acre. Brasília, Embrapa Recursos Genéticos e Biotecnologia (Boletim de Pesquisa e Desenvolvimento), $21 \mathrm{p}$.

Silva, W da, RS Santos, LC Magalhães \& EMRS Dantas, 2018. Dinâmica populacional de Gargaphia paula e Tetranychus ogmophallos em amendoim forrageiro no Acre. Rio Branco: Embrapa Acre (Eventos Técnicos \& Científicos, 1), 4 p.

Thomazini, MJ, ES Albuquerque \& MF Souza-Filho, 2003. Primeiro registro de espécies de Anastrepha (Diptera: Tephritidae) no estado do Acre. Neotropical Entomology, 32: 723-724. DOI: https://doi.org/10.1590/S1519$566 \times 2003000400027$

Thomazini, MJ \& ES Albuquerque, 2009. Parasitóides (Hymenoptera: Braconidae) de Anastrepha Schiner (Diptera: Tephritidae) no estado do Acre. Acta Amazonica, 39: 245-248. DOI: https://doi.org/10.1590/S004459672009000100030

Valentim, JF \& CMS de Andrade, 2003. Benefícios ambientais do uso de tecnologias na pecuária. Available on: <https:// ambientes.ambientebrasil.com.br/agropecuario/ artigo_agropecuario/beneficios_ambientais_do_uso_de_ tecnologias_na_pecuaria.html>. [Access in: 17.ii.2019].

Vasconcelos, AS, TS Azevedo \& RS Santos, 2017. Primeiro registro de Zaprionus indianus Gupta (Diptera: Drosophilidae) no Estado do Acre, Brasil. EntomoBrasilis, 10: 60-63. DOI: https://doi.org/10.12741/ebrasilis. v10i1.670

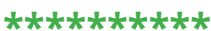

Suggestion citation:

Sutil, WP \& RS Santos, 2020. Agricultural entomology in the state of Acre, Brazil: a historical overview and future challenges. EntomoBrasilis, 13: e0878.

Available on: doi: 10.12741/ebrasilis.v13.e0878
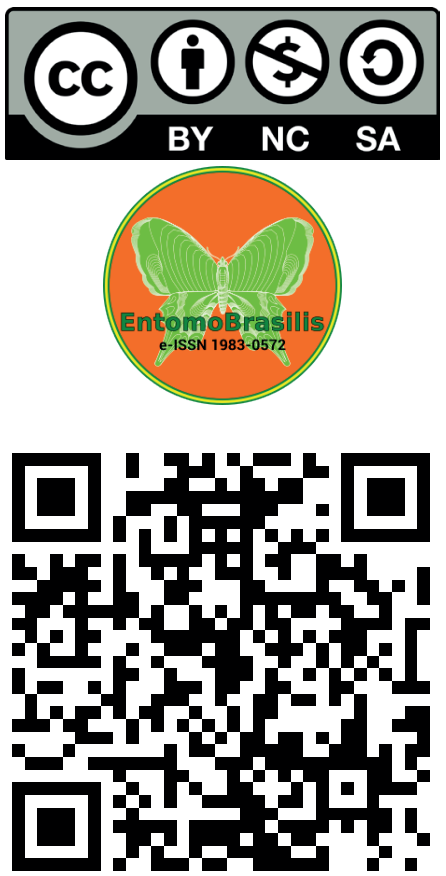